\title{
Challenges for Indonesian Government in Controlling Illegal Fishing in Legal Perspective (Study in North Sumatera Province)
}

\author{
Mohammad Eka Putra ${ }^{1}$, Vita Cita Emia Tarigan ${ }^{2}$ \\ ${ }^{1}$ Universitas Sumatera Utara, Faculty of Law, Medan, North Sumatera, Indonesia \\ ${ }^{2}$ Universitas Pembangunan Panca Budi, Faculty of Social Science, Medan, North Sumatera, Indonesia \\ Corresponding Author: Mohammad Eka Putra
}

DOI: https://doi.org/10.52403/ijrr.20220161

\section{ABSTRACT}

The provincial government of North Sumatera has vast maritime and fisheries potential, consisting of the potential for catching fisheries and for cultural fisheries. The potential of the catchment of the North Sumatera Province of the Straits of Malacca is 484,414 per year, and the potential of the Indian Ocean is 1,228,601 per year. Given the magnitude of the less exploited fisheries potential, which has led to North Sumatera Province becoming a fertile ground for Illegal, Unreported, Unregulated Fishing, or commonly mentioned as IUU Fishing,

The current study uses the normative jurisprudence methodology, which is based on the main legal material by examining the theories, concepts, legal principles, and legislative rules. The type and nature of the research used is qualitative research with legal and policy approaches around IUU Fishing. The data sources used are secondary data sources using primary legal materials, secondary legal materials, and tertiary legal materials. Data collection techniques in this paper used library study and the results will be repeated to the respondents who have been determined.

The Ministry of Marine Affairs and Fisheries implemented three pillars to prevent and address the activities of IUU fishing, known as the three pillars policy, namely: sovereignty, sustainability, and welfare. That has been implemented in some of the ways among the ships that commit illegal fishing crimes for the deterrent effect; performing the moratorium on foreign vessels; the establishment of an
\end{abstract}

eradication task force on illegal fishing 115 . The many achievements undertaken by the Ministry of Maritime Fisheries are not accompanied by consistent efforts in the eradication efforts of IUU fishing in Indonesia.

Keywords: IUU Fishing, Illegal Fishing, Ministry of Marine Affairs and Fisheries

\section{INTRODUCTION}

The province of North Sumatera is located in the western part of Indonesia based on its geographical location, which is located between 10-40 LU, 980-1000 B.T. The capital city of North Sumatera province is located in Medan City. This area itself consists of beaches and lowlands to the east and west, while the highland areas are Karo, Toba, and Humbang Hasudutan. The province's borders are divided into three parts: the north by the province of Aceh, the east by the Strait of Malacca, the southern border by the provinces of Riau and West Sumatera province, and the west by the Indian Ocean. The area of North Sumatera reaches 18,298,123 ha $(182,981.23 \mathrm{~km} 2)$, which consists of a land area of 7,298,123 $\mathrm{km} 2$ and an ocean area of 11,000,000 km2 (BPS North Sumatera Province; 2015).

According to the provincial government of North Sumatera, the potential for marine and fishing activities is vast, consisting of the potential for catching waters and the potential for cultural fisheries. The catchment potential in the 
Straits of Malacca is 484,414 tonnes/year and the potential in the Indian Ocean is 1,228,601 tonnes/year (sumutprov.go.id). Meanwhile, the number of fishermen currently stands at 250 thousand along the east coast (Straits of Malacca) and the west coast (Indian Ocean). (business.com, daily.com). Unfortunately, $95 \%$ of these fishermen are traditional fishermen and small fishermen who still have limited access to the outlying waters of Indonesia.

Given the magnitude of this underutilized fishing potential, North Sumatera Province has become a fertile ground for Illegal, Unreported, Unregulated Fishing also commonly known as IUU Fishing. According to the former Minister of Marine and Fisheries of the Republic of Indonesia, Mrs. Susi Pudjiastuti, there are two types of IUU fishing practices in Indonesia, namely: 1) fishing practices by foreign fishermen and 2) fishing practices that are destructive by local fishermen. (KKP News). In the province of North Sumatera, fish theft cases are the most common, with an estimated loss of 875 billion rupiah annually (Kompas.com). Fishermen from Thailand, Vietnam, the Philippines, and Malaysia have become the largest foreign fishermen who do most IUU fishing in the region. To follow up on this matter, the Government of Indonesia, through the Ministry of Marine Affairs and Fisheries, has established an Illegal Catch Eradication Task Force or Task Force 115, through Presidential Decree No. 115 of the Year 2015, one of whose duties is to develop and implement law enforcement in illegal eradication of fish through crossagency coordination (Kompas 12/01/2020). As for some breakthroughs and policies that have been taken by this task force, among them, the analysis and evaluation of the compliance of 1,132 ex-foreign vessels, the action on the transmission of illegal fish vessels, as many as 516 illegal fish vessels until May 2019, and the handling of 1020 people's human slavery in Benjina Maluku.

However, as the term of this task expires on December 31, 2019, causing the vacancy of personnel, this follows the narrative of Mas Achmad Santosa, who states that the institution still exists but the personnel no longer exist due to the absence of the new President's instructions (Kompas 12/1/2020). While the new Minister of Marine and Fisheries, Mr. Edhy Prabowo, still reviews several regulations, one of which is the task force's time, budget, and performance evaluation. Therefore, it is necessary to see how the IUU fishing policy has changed in North Sumatera province after the transition of the Ministry of Marine Affairs and Fisheries from Mrs. Susi Pudjiastuti in the Indonesia Working Cabinet era to Mr. Edhy Prabowo in the era of the Indonesia Advancing Cabinet for North Sumatera province.

\section{RESEARCH METHOD}

This study uses the normative juridical methodology in its methodology, which is based on the main legal material by studying the theories, concepts, legal principles, and laws related to this study to find the truth under the logic of legal science in terms of normatively (Ibrahim, 2006). The type and nature of research used is qualitative research with the approach of legislation and policies around IUU fishing. This approach is used to find out whether the laws and policies on IUU fishing that have been adopted by Minister Mrs. Susi Pudjastuti have changed in the transition era led by the Ministry of Marine and Fisheries, Mr. Edhy Prabowo.

The data source used is a secondary data source using primary legal materials, secondary legal materials, and tertiary legal materials. The primary legal material itself is derived from all regulations and policies that are related to IUU fishing; secondary legal materials are derived from expert opinion, research results, textbooks, and journals on IUU fishing policy; and tertiary legal materials are obtained from dictionaries and legal encyclopedias. The data collection techniques in this paper use library studies, and the results will be repeated to the respondents who have been 
determined. The descriptive qualitative method was used to analyze all of the data.Some of the respondents are Andreas Sinulingga, Design and Development of the Directorate General of Maritime Affairs, Ministry of Communications of the Main Port Authority of Belawan, and Boy Bronso Simarmata, Navigation and Maritime Affairs of the Ministry of Transportation. Directorate General of Maritime Affairs, Ministry of Transportation. It is used to know for sure what is happening in the field in terms of the IUU fishing policy after the transfer of the Ministry of Marine and Fisheries from Minister Mrs. Susi Pudjiastuti to Minister Mr. Edhy Prabowo.

\section{DISCUSSION}

\section{IUU Fishing in North Sumatera}

Basically, in literal terminology, Illegal, Unreported, and Unregulated (IUU) fishing comes from the word "illegal", which is a violation, dark, wild, and illegal entry (Shadily, 2003), and "fishing" is to find fish by boat, rods, and lures. In other dictionaries, it is stated that "illegal" means unauthorized, prohibited, or contrary to law (Salim, 2003), and "fishing" means fishing as a livelihood (Shadily, 2003). Thus, the terminology above concludes that illegal fishing is an unauthorized fishing activity that is contrary to the law.

According to FAO, IUU fishing activity is a variety and dimension of illegal fishing activities in both the offshore and the national jurisdiction area of the country that consist of catching and using fish (Nations, 2020), carried out by foreign national vessels in the waters under the jurisdiction of a country without the permission of the country, or contrary to its law and its arrangement, or conducted by vessels operating with no conservation and management measures, and contrary to national and international laws. IUU fishing consists of illegal fishing and unreported fishing. Any fishing activities conducted by foreigners and/or foreign vessels in water that becomes the jurisdiction of a country without the permission of the country, or contrary to the prevailing laws and regulations in the country where fishing activities are held, are considered illegal fishing activities. Any fishing activity that violates applicable national and/or international regulations; Every fishing activity carried out by the ship while raising the flag of a country that is a member of a regional fisheries management organization but whose operation does not agree with the provisions of the preservation and management adopted by the organization or the provisions of international law in force. In the region of Indonesia in general and North Sumatera in particular, a common activity is unlicensed fishing, using false clearance using prohibited capture and fishing (species) that do not agree with the permission given.

The activities of unreported fishing are Every fishing activity conducted in the area under the authority of regional fisheries management institutions that is never reported and/or reported incorrectly or not following the reporting provisions established by the institution. Generally, activities that usually occur in Indonesia and North Sumatera province include fishing that does not report the actual catches or data counterfeiting of the catch. The catch is directly brought to other countries (transshipment in the middle of the sea).

Including the fishing activities that are part of the regulated. Fishing is any fishing activity in an area whose conditions have not been established and have not implemented preservation and management, so it is done irresponsibly and does not conform to the principle of preservation and management of fish resources by international rules. Every fishing activity carried out in an area that is under the authority of a regional fisheries management institution/organization, conducted by a non-citizenship vessel, or that is waving a flag of a country that is not a member of that organization, in a manner that does not conform to the preservation and management provisions of the organization. The usual activities in 
Indonesia in general and in the province of North Sumatera in particular, are fishing activities where the mechanism of recording the capture results has not been arranged in detail, as well as areas that are allowed and not allowed to catch fish, and still not in the sport of fishing and activities that use modifications to other fishing equipment.

According to the Ministry of Maritime and Fisheries, there are 12 modus operandi of IUU Fishing in Indonesia generally, and in the province of North Sumatera in particular, such as counterfeiting ship registration documents, catching fish without shipping documents, do not activate the vessel monitoring transmitter, use of prohibited fishing equipment, and do not put fish in the port specified in the permit. Also, some fishermen use illegal methods, such as using cyanide or fish bombs, catching fish in unset places or selling without clear data and some other activities. Usually, these activities arise not only because there is no clear regulation but also because of a lack of supervision and infrastructure support.

IUU fishing activity itself has a lot of adverse effects on both the continuity of the environment and the fish itself, inflicting a lot of harm on the country. The estimated loss of Indonesia is not less than 2,000 trillion rupiah annually as a result of IUU fishing activities (Indonesia, 2020).

Therefore, the Ministry of Marine and Fisheries implemented three pillars to prevent and overcome the activities of IUU fishing, also known as the policy name, three pillars of the pillar of sovereignty, sustainability, and welfare (Sistiyanto, 2018). That has been implemented in some of the areas among the ships that commit illegal fishing crimes for deterrent effect: conducting a moratorium on foreign vessels; the establishment of an eradication task force on illegal fishing 115 .

The Indonesian Illegal Fishing legislation is governed by (1) Law No. 45 of 2009 on Fisheries, which deals with matters relating to IUU Fishing related to the prohibition of fishing, the obligation to maintain a plasma pool, and sanctions that will be given. (2) Law No. 5 of 1983 on Indonesia's exclusive economic zone.The thing related to IUU fishing is about setting a ZEE boundary line that is often used by IUU fishing actors to escape or circumvent, namely article 4 paragraph (3), which states "in the exclusive economic zone of Indonesia, the freedom of shipping and international flights and the freedom of installation of cables and undersea pipes are recognized by the principles of international law of the applicable Article 5 paragraph (3), which reads: "By not reducing the provisions of article 4 paragraph (2), the exploration and exploitation of natural resources in certain areas in the exclusive economic zone of Indonesia by persons or legal entities or foreign governments may be permitted if the number of catches allowed by the government of Indonesia for such type exceeds the ability of Indonesia to exploit them." Unfortunately, there is no firmness about IUU fishing. (3) Law No. 21 of 1992, relating to sailing. The thing related to IUU fishing lies in the frequent actors. IUU fishing is also often accompanied by a criminal act of shipping, such as breaking traffic ordinances, shipping flows, and others. (4) Law No. 6 of 1996 on Indonesian waters: things related to IUU fishing are located in the division of Indonesian Water Territory. Therefore, it becomes a reference if the vessels that do IUU fishing are ensnared with this law.

\section{IUU Fishing Policy in the Indonesian cabinet era advanced in North Sumatera province}

The Advanced Indonesian Cabinet is the government cabinet of Mr. Joko Widodo and Mr. Ma'aruf Amin. This Cabinet consists of eight Ministerial-level Officers, 34 Ministers, and 12 Deputy Ministers who were appointed on October 23, 2019. One of the ministers appointed was the Minister of Maritime Affairs and Fisheries, Mr. Edhy Prabowo. Along with the transition of the Minister from Mrs. Susi Pudjiastuti to Mr. Edhy Prabowo, several policy shifts were 
also implemented, one of which was the IUU fishing policy.

One of the most visible is the stipulation of 100 days of work programs, according to the website kkp.go.id. The things that have been done include (1) Implement licensing reforms by launching an online-based Fast Service Permit Information System that reduces the time it takes to obtain permits for fishing vessels larger than 30 feet from 14 days to one hour.(2) the arrest of foreign fish smugglers on three Philippine ships in the Sulawesi Sea, one Malaysian ship in the Malacca Strait, and three Vietnamese ships in the North Natuna Sea. (3) Exemption from Indonesian fishing ship KM Abadi, which was arrested by the Malaysian Maritime Enforcement Agency in the year 2016 in the Straits of Malacca. (4) Increasing Cooperation with Community, Regional Heads, and International.

Many of the achievements made by the Ministry of Marine Fisheries are not commensurate with the consistent efforts to eradicate IUU fishing in Indonesia. This can be seen from the ambiguity of the fate of the Illegal Fisheries Eradication Task Force (Task Force 115). Because until now, although it has been decided to continue in the limited coordination meeting chaired by the coordinating minister for politics, law and human rights on January 23, 2020, and continued in the initial coordination meeting of the task force 115 on May 20, 2020, There is still no clarity related to SOP, technical guidelines, budget, and overlap in the authority of this task force. This is due to the fact that the process of evaluating and reviewing the performance of this task (115) is still ongoing.

According to member commission IV DPR RI, Mr. Darori Wonodipuro, it happened because there are still many cases of illegal fishing although the Task Force has been working for 5 years, and the occurrence of double the budget is the result of the fact that the members of this task force are filled by several other institutions such as soldiers and police. As coordinator of task staff of the 115 Task Force, Mas Achmad Santosa stated that there are three options for the sustainability of the task force. 1) incorporated into the main tasks and functions of the KKP, Bakamla, or other institutions. 2) Its responsibilities were expanded.3) It was dissolved because it was no longer needed.

The unclear position of Task Force 115 resulted in the IUU fishing policy apparently not working. Although the existence of the task force still exists, the members and the implementation of their duties and functions are not running optimally. Something similar also happened in North Sumatera Province.

Although the existence of Task Force 115 was not running optimally, the IUU fishing policy continued. These include Andreas Sinulingga, Design and Development of the Directorate General of Sea Transportation, the Ministry of Transportation of the Main Port Authority of Belawan, and Boy Bronso Simarmata, Navigation and Sea Transportation of the Ministry of Transportation. The Directorate General of Sea Transportation, the Ministry of Transportation stated that the main duties and functions of the eradication of IUU fishing are still being carried out by their respective agencies because the implementation of the IUU Fishing Policy is not only attached to the Ministry of Maritime Affairs and Fisheries and Task Force 115 alone.

\section{CONCLUSION}

The underutilized fishery potential causes North Sumatera Province to become fertile ground for Illegal, Unreported, Unregulated Fishing, or commonly called IUU Fishing. To follow up on this, the Government of Indonesia, through the Ministry of Maritime Affairs and Fisheries, has established a Task Force to Eradicate Illegal Catching, or Task Force115, through Presidential Regulation Number 115 of the Year 2015, in which one of their tasks is to develop and implement law enforcement in 
Mohammad Eka Putra et.al. Challenges for Indonesian government in controlling illegal fishing in legal perspective (study in North Sumatera Province).

illegal eradication of fish through crossagency coordination.

The Ministry of Maritime Affairs and Fisheries applies three pillars to prevent and overcome this IUU fishing activity, known as the Pillar of Sovereignty, Sustainability, and Welfare. Things that have been implemented for many activities include sinking ships that commit illegal fishing crimes for deterrent or deterrent effects; a moratorium on foreign ships; and the establishment of an illegal fishing eradication task force 115 .

Due to Task Force 115's ambiguous existence, the IUU fishing policy has stagnated, despite the task force's continued presence. Members and the task force's execution of tasks and functions are unable to operate properly. This also occurred in the province of North Sumatera. The primary tasks and functions associated with eradicating IUU fishing continue to be carried out by their respective agencies, since the execution of the IUU fishing policy is not solely the responsibility of the Ministry of Maritime Affairs and Fisheries and Task Force 115.

Acknowledgement: None

Conflict of Interest: None

Source of Funding: None

\section{REFERENCES}

1. Ibrahim, J. (2006). Teori dan metodologi penelitian hukum normatif. Malang: Bayumedia Publishing, 57.

2. Echols, J. M., \& Shadily, H. (2003). Kamus Inggris Indonesia (An English-Indonesian Dictionary), Cet. XXIV (Jakarta: PT. Gramedia Pustaka Utama, 2000).

3. Salim, P. (2003). The Contemporary English Indonesian Dictionary, Modern English Press.

4. "What is IUU Fishing?" Food and Agriculture Organization of the United Nations. Available at http://www.fao.org/iuufishing/background/what-is-iuu-fishing/en (Accessed, 5 May 2020)

5. CNBC Indonesia (2018). "Susi Akui RI Pernah Rugi Rp. $2.000 \mathrm{~T}$ Akibat Illegal Fishing." Available at https://www.cnbcindonesia.com/news/2018 0626075822-4-20458/susi-akui-ri-pernahrugi-rp-2000-t-akibat-illegal-fishing

(Accessed, 6 May 2020)

6. Sistiyanto, Harjuno. (2018). "IUU Fishing dan Ancaman Kedepannya Bagi Indonesia" Kementrian Kelautan dan Perikanan. Available at https://kkp/go.id/brsdm/artikel/5684-iuufishing-dan-ancaman-kedepannya-bagiindonesia (Accessed, 6 May, 2020)

How to cite this article: Mohammad Eka Putra, Vita Cita Emia Tarigan. Challenges for Indonesian government in controlling illegal fishing in legal perspective (study in North Sumatera Province). International Journal of Research and Review. 2022; 9(1): 528-533. DOI: https://doi.org/10.52403/ijrr.20220161 